\title{
Reflective Core Values the Life of the Sundanese
}

\author{
An Integration Embeds the Value of Sundanese
}

\author{
Asep Sjamsulbachri, Deni Zein Tarsidi \\ Faculty of Teacher Training and Education \\ Pasundan University \\ Bandung, Indonesia \\ asepsjamsulbachri123@gmail.com
}

\begin{abstract}
Today, there are many Sundanese who do not have the typical personality and behavior of Sundanese people. Through this research, it is expected to get a picture of the phenomenon of instilling the values of Sundanese by habituation. The method used in this research is phenomenology method, with data collection techniques through observation, interview and documentation analysis. The results of this study are: Sundanese cultural moral values that are implemented in campus life create an atmosphere of harmony among leaders, lecturers, employees and students, so that the same harmonious atmosphere is experienced among students in campus life even though they come from different ethnicities, religions and cultures, and even it is experienced amongst foreign students who study here, both undergraduate and postgraduate level. The existence of Sundanese Core Value that crystallizes in the motto of luhung elmuna (high in knowledge), pengkuh agamana (strong religion), and jembar budayana (rich in cultures) for each graduate. The activities of Tri Dharma Perguruan Tinggi (three college assignments) is not enough to reach the values, but its typical mission of maintaining Sundanese culture and glorifying Islam appears in the campus atmosphere, tolerance of mutual respect and Silih Asih (love), Silih Asah (mutual coaching), Silih Asuh (mutual care) among the student.
\end{abstract}

Keywords - core values; sundanese society; sundanese

\section{INTRODUCTION}

Globalization is a fact that we cannot deny anymore so that knowledge and technology become two things that cannot be separated from each other. According to A. Qodri Azizy [1], the key word of globalization is competition. So that globalization provides opportunities and facilities for all people who are willing and able to use it both for their own sake and for human interests. Globalization has penetrated all corners of the world even into remote areas, able to break through the gates of moral defense and religion as strongly as possible. Morality becomes loose something that was previously considered taboo, now it becomes normal. How to dress, interact with the opposite sex, enjoy drugs and entertainment places is one of the trends in the modern world that is difficult to overcome.

Family life and Sundanese society, especially those living in urban areas, experience changes due to the rapid flow of globalization. In connection with the manifestation of culture as a complex of ideas and ideas, complex patterned activities and social systems with human work that must be preserved are also preserved so the shift in cultural values can be categorized as a very worrying phenomenon. Ethnic Sundanese are native tatar Pasundan who have the characteristics of culture, language, religion, tradition, livelihood, as well as various unique ancestral cultural heritage. For Sundanese people, the Sundanese cultural moral values are a strong fortress to face the changing times in this era of globalization.

Before independence, Indonesia in its cultural history had gone through periods of great empire and colonialism which stretched in a matter of centuries, this greatly affected the world of education, especially character education. During the Dutch colonial period, the indigenous people known as boemi poetra were given limited opportunities to receive education. Through ethical politics, the Dutch only allow certain natives who can get formal education.

Planting the character of the nation, especially in the Sunda region, at that time more was done informally, this was as seen in the aim of planting values that parents should teach their children to: "ngomean adat bawa ti koedrat soepaya toeloeytoeloey tepi ka kolot salamet, kadeuleu koe sanak baraya, ari geus kolot eta boedak tangtoe di regepkeun papatahna, di toeroetan kalakoeanana" which mean Character Education to improve an innate attitude that is not good enough to be good so that his life survives to old age and his practice and advice are exemplified by his family [2].

Whereas in formal education one of the forms of struggle of the Sundanese people was through the Pasundan Circle of Friends (1913) which had the educational objectives of Pasundan namely: anoe djadi poko loeloegoe djudul atikan njeeta ngawangun pamake baroedak soepaja djadi djelama sampoerna, maksoedna awewe lalaki waspada, matang pamilih, pangadjen, koekoeh enggoning njieun poetoesan, temen wekel di pake ageman, kalajan satia kana poetosan pribadi dina enggoning roemingkang saliring doemadi, which means: "The purpose of education is to build the character of children in order to become a perfect human being both male and parable by having a vigilant attitude towards a strong personality, self-esteem, firm stance and loyal to personal envoys in the face of life [3].

The world of education must help children to understand core values, adhere to and practice them in their lives, because ultimately the individual character will shape the character of 
the community which in turn will characterize the character of a nation.

\section{METHOD}

Methodologically, this study will use a qualitative paradigm with phenomenological research design. Data collection techniques through: interviews, observation and documentation studies of students, lecturers, leaders, and employees of the Pasundan University. Because this study belongs to the phenomenological study category, the flow of data analysis follows what Creswell said, as follows:

- Researchers begin by describing their experience thoroughly

- The researcher then finds a statement about how people understand the topic, details of the statements and treats each statement of equal value, and develops the details by not repeating or overlapping.

- The statements are then grouped into meaningful units, the researchers specify the units and write a textual description of their experiences, including the examples carefully.

- The researcher then reflects his thoughts and uses imaginative variation or structural description, looking for all possible meanings and through divergent perspectives, considering the frame of reference for the phenomenon, and constructing how the symptoms experienced.

- The researcher then constructs all of his explanations about the meaning and essence of his experience.

- The process is the first step researchers reveal their experiences, and then followed the experience of all participants. After all that is done, then write the description of the combination (Creswell, 1998, pp. 147-150).

\section{RESULT AND DISCUSSION}

Value is the core of the cultural system. This is as Lautan said that 'the core of the culture consists of traditional concepts in general and the value system in particular.' Enclosed values in a culture, if there is a change in value then cultural changes also occur including human attitudes and behavior in social life, nation and state. According to Gazali, et al. [5] that: Cultural value is an abstract conception of basic issues that are very important and valuable in the lives of human society. A system of cultural values consists of several elements of elements, namely: religious value, value of knowledge, social value, economic value, artistic value. Religious values are the basis for cultural formation. The value of knowledge involves logical and rational considerations in proving something right or wrong. Social values are related to love between humans such as mutual cooperation, tolerance, tolerance, and others. Economic value is to assess profit and loss. While the artistic value is related to beauty and harmony. According to Amin that: The results of creativity, intention, and work that is high in artistic value, the value of its beauty, the value of its ornaments reflect a high culture, also reflects the quality of creation and work, reflecting also the high quality, and also reflecting high dignity and the character of the nation's children
[6]. Therefore, to achieve the dignified character of the nation, high cultural values are needed in terms of art, beauty and ornamentation. Human reason is a tool used in creating values that are the basis for behavior related to human culture. Spranger describes the concept that human values can be distinguished in [7]:

- The value of theory, as incarnated in science and knowledge;

- Economic value commonly called utility or utility;

- Religious values in the form of holiness or holiness;

- Aesthetic values called expressiveness or expression;

- Vertical social value, namely power that is primarily incarnated in political behavior and relations;

- Horizontal social value that is solidarity that manifests as love, friendship and cooperation.

Based on these values the dominant value is the value of religion which subordinates all other values to logic, law and reality. The values contained in that culture are reflected in the behavior of every human being. This is as revealed by Lutan that "most social activities in a society are directed or controlled by culture, values and norms" [8]. Local cultural values are interpreted as social identities that need to be communicated or delivered to the community. Value is seen as something valuable by a person or group of people and is used as a reference for action and a reference to life.

Cultural values obtained from the learning process produce certain attitudes and behaviors that can build the nation's character. Koentjaraningrat explains that cultural value systems suitable for development include [9]:

- Active attitude, endeavor and not fatalistic;

- Orientation to the work, improvement of works;

- Orientation to master nature;

- Future life orientation;

- Cooperation orientation.

These five value orientations are suitable for development, including in national development to maintain the character of the Indonesian nation. Then it is necessary to develop an understanding of values in culture so that it can have an impact on the sustainability of our nation's identity. Ekadjati said that Sundanese cultural moral values are Sundanese ethnic identity which originated in the values, beliefs and relics of Sundanese culture and used as a reference in acting [10]. For Sundanese people Sundanese cultural moral values are a strong fortress to face the era of globalization. According to Rusyana the moral values of Sundanese culture are the values possessed by the Sundanese people which are believed to be inherent and lead to the determination of the Sundanese people to make it happen [11]. It contained a basic concept of life formed by humans and Sundanese people. Systematically illustrated in the following figure: 


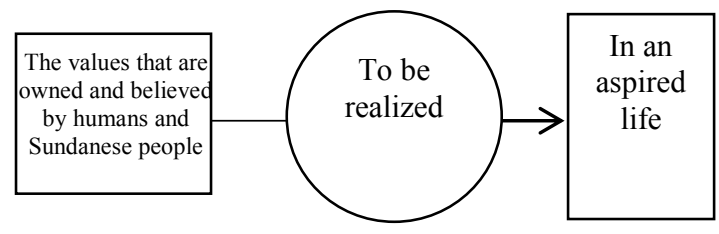

Fig. 1. Systematics of Realizing Value in the Sundanese Community

Processed by: Rusyana [11].

This process will last a lifetime through education, both formal education by schools and informally by families and communities. The emphasis on formal and informal educational goals is on character building through exemplary in personal contexts and in life in society, surviving in relationships horizontally and vertically. With education, it will arise in a person to compete and motivate ourselves to be better in all aspects of life. Education is one of the conditions for further advancing this government, so try education from elementary school to university level.

The purpose of National Education in the 1945 Constitution (version of the Amendment), Article 31, paragraph 3 states, "The Government seeks and organizes a national education system, which enhances faith and piety and noble morals in the context of intellectual life of the nation, which is regulated by law.", Article 31, paragraph 5 states, "The Government promotes science and technology by supporting high religious values and national unity for the advancement of civilization and the welfare of mankind."

Whereas National Education Objectives in Law No. 20, Year 2003, Article 3 states, "National education functions to develop the ability and shape of dignified national character and civilization in order to educate the life of the nation, aiming to develop the potential of students to become faithful and fearful people of God Almighty, noble, healthy, knowledgeable, capable, creative, independent, and a democratic and responsible citizen" [12,13].

The effort to form the nation's character in its administration must be in line with the nuances of the potential of a pluralistic society, so that Indonesian national identity will emerge in a vehicle for diversity that can minimize the emergence of jealousy between ethnic, cultural and religious as well as avoid the emergence of national disintegration [14].

The formation of the character and character of the nation through education is emphasized on appreciation and practice of moral values, the development of abilities and kecapakan and the discipline of discipline and habituation of commendable attitudes. Emphasis on these three aspects is a form of proportional and balanced development of the affective, cognitive and psychomotor domains. The behaviors that appear from the empowerment of these two institutions bring a peaceful, tolerant campus atmosphere, a sense of mutual love and respect, including Pasundan University's extended family despite their different religions.

Sundanese ethnicity has several philosophies in its life. one of the philosophies is three self-identity pasundan namely luhung elmuna (high in knowledge), jembar budayana (rich in cultures), pengkuh agamana (strong religion). Luhung elmuna (high in knowledge) reviewed from Sanghyang Siksa Kandung Karesian compiled in 1518 was introduced by K.F Hole [15]. To Sanghyang Siksa Kandung Karesian, Ayatrohaedi [16] mentions as a guideline for living and knowledge of Sundanese peoples as for luhung elmuna (high in knowledge) reviewed from Amanat Galunggung V Rekto sheets: 2, that sounds rapes dina oerang agama ni pare-masana djoemaroen teuleu daoen masana diojas-gede pare-masana boeloe ireong-beukahtarakah-noenjoenk lalangit. which means: "as for perfect charity is the science of rice: when sprouting as big as a needle, leaves come out, when we are weeded grow up, out buds, blooms of fruit pointing up at the sky, looking up, beautiful, when it arrives arrived when ducking, yellowing, cooking downward because of yourself after side by side [17]. In the life of a Sundanese, if a Sundanese person has been equipped with knowledge, he must be able to remain humble and not arrogant, as the science of rice grows increasingly drooping. Humility does not mean helplessness, but we will be humbly loved by many who can have an impact on a more orderly social life. In a campus environment, a student may not boast about being a student but must be able to maintain his humility, because everyone in the eyes of God is no different.

Pengkuh agamana (strong religion) reviewed from Amanat Galunggung V Rekto sheets:3, which reads: ngasupkeun hulun jarang midukaan, nanya kanu karwlwat mawa toeh sabab na agama pun, sasana buat kwalwat pun hana nguni hana mangke. Which means: "ask the parents, undoubtedly will not despise, get lost from religion, that is the law made by the ancestors, there was formerly there [17]. Internalization in strengthening religion is very important, because religion is a milestone for the creation of a good character climate. Here, religion is not only used as my ritual, but is used as a guide to life. The campus environment must be supported by a strong religion as a basic foundation for creating a conducive campus climate.

Jembar Budayana (rich in cultures) can be studied from Amanat Galunggung VI Verso: 2 which reads: nu takut sapa, nurut dina menak di gusti panghulu, reya kabisa, prijnya, cangcingan, gapitan iya galah condok tinugelan teka ngarana. Which means: "those who are the main ones who fear fear, obey noble people, landowners and rulers, have many skills, are intelligent, deft, skilled, like a puncture pole cut sharply by name, do not waste our good deeds if so [17]. Preserving Sundanese culture occurs through habituation, one of them is by calling "akang / teteh (brother/sister)" when calling students. In addition, in preserving the culture of subda, it is also given through the Sundanese cultural courses which are the typical subjects of Pasundan University. Because Sundanese Culture is one part of national culture that must be maintained, in order to become a national force in the face of negative cultural attacks in the current of globalization.

So in the preservation of the Sundanese people's identity has been applied in the pattern of hybridization, habituation is a process of instilling a value continuously so that it can be embedded in someone [18]. Habituation in instilling the values of local wisdom on campus as a campus identity will have a positive impact on the campus, namely in the form of being able to preserve these values in all circles in the campus. 


\section{CONCLUSION}

The atmosphere of campus life in harmonious communication between leaders, lecturers, employees, and students that harmoniously shows signs of a tolerance society that can counteract the narrow primordialism and radicalism. The existence of two LBS institutions (Sunda Cultural Institution) and LP2SI (Islamic Sharia Assessment and Dissemination Institute) in Unpas sows the individual, ethnic, and national adherence that needs to be developed. There needs to be engineering to maintain a good atmosphere and complement something that is still lacking so that the core value of Sundanese will strengthen the nation's core value (Pancasila) which is an open ideology.

\section{REFERENCES}

[1] Azizy A. Qodri.(2004). Melawan globalisasi reinterpretasi ajaran Islam: persiapan SDM dan terciptanya masyarakat madani. Yogyakarta: Pustaka Pelajar.

[2] Mustafa, Hasan H. (1913). Adat Istiadat Oerang Soenda. Jogjakarta: Rekasarasin.

[3] Djadiningrat, PAA. (1939). Factoren Voor De Vooruitgang Van Indonesie. Djakarta: Commissie Redactie Pagoejoeban Pasoendan.

[4] Creswell, John W., 1998, Qualitative Inquiry and Research Design: Choosing Among Five Traditions, Sage Publications Inc. USA.
[5] Gazali, et al. 1997.

[6] Amin J, Regander J. The effect of competition on the creativity and motivation of Swedish school children (Bachelor thesis). Department of Psychology, Lund University, Sweden. 2011.

[7] Spranger. E. (1928). The Tipe on Man The Psychology and Etnich of Personality. Max Niemeyer Verlg, Hall (saale).

[8] Lutan, Rusli. (2001). Keniscayaan pluralitas budaya daerah analisis dampak sistem nilai budaya terhadap eksistensi bangsa. Bandung : Angkasa.

[9] Koentjaraningrat.(2000).Pengantar Ilmu Antropologi.Jakarta: Rineka Cipta

[10] Ekadjati, Edi S. (1995). Kebudayaan Sunda. Jakarta: Pustaka Jaya.

[11] Rusyana, Yus. (1991). Bagbagan Puisi Pupujian Sunda. Bandung: Proyek Penelitian Pantun dan Folklore Sunda.

[12] Undang-Undang Dasar Negara Republik Indonesia 1945 Amandemen IV.

[13] UU Nomor 20 Tahun 2003 Tentang Sistem Pendidikan Nasional

[14] Adimihardja, Kusnaka. (1999). Dialog Kebudayaan. Jakarta: ISPI Pusat.

[15] K.F Hole. 1867.

[16] Ayatrohaedi. (2003). Pedoman Penelitian Dialektologi. Jakarta: Pusat Bahasa.

[17] Atja, Salah Darsanasasmita. (1981). Amanat dari Galunggung. Bandung: Proyek Permusiuman di Jawa Barat.

[18] Susanto, 2017. 